\title{
Kepastian Hukum Kedudukan Camat sebagai PPAT Sementara \\ Legal Certainty of The Position Sub-district Head as Temporaly Land Deed Officer
}

\author{
Irfan Iryadi \\ Alumnus Program Doktor Ilmu Hukum Fakultas Hukum-Universitas Diponegoro \\ Jln. Imam Bardjo No. 1 Kota Semarang - Jawa Tengah \\ email: irfan.aceray@gmail.com \\ Naskah diterima: 4 Januari 2020 \\ Naskah direvisi: 22 April 2020 \\ Naskah diterbitkan: 1 Juni 2020
}

\begin{abstract}
After the enactment of Government Regulation Number 24 of 2016, the provisions regarding dual positions as civil servants become one of the substances regulated by this Government Regulation. The existence of these provisions has led to the blurring of norms over the head of sub-district's position as temporary land deed officers in creating an authentic deed in the land sector. Based on this legal issue, this article was written with the aim of finding out the status of the head of sub-district's position as temporary land deed officer and offering a concept that should be implemented when temporary land deed officer's position is needed. The results showed that in Government Regulation Number 24 of 2016, there was no legal certainty in the formulation of the article as a result of the blurring of legal norms over officer assigned to the temporary land deed position. This obscurity can be seen from designation of the temporary land deed officer to the head of sub-district, where the head of sub-district is a State Administration Officer that is contrary to the land deed officer's rules that prohibit land deed officer from being held by Civil Servants. The task of temporary land deed officer should be transferred to the head of village, since the head of village's position has already been acknowledged and accommodated in the land deed officer's rules as temporary land deed officer. This alternative is considered to provide more legal certainty and an ideal solution to the status of temporary land deed officer. Therefore, it is recommended to stakeholders in the land sector, on matters regarding the land deed officer, to conduct further assessment on this idea in order to be implemented in the assignment of temporary land deed officer in Indonesia.
\end{abstract}

Keywords: head of sub-district; temporary land deed officers; legal certainty

\begin{abstract}
Abstrak
Pasca berlakunya Peraturan Pemerintah Nomor 24 Tahun 2016, aturan mengenai rangkap jabatan sebagai pegawai negeri menjadi salah satu substansi yang diatur Peraturan Pemerintah itu. Adanya ketentuan itu telah menimbulkan kekaburan norma atas kedudukan Camat sebagai PPAT Sementara dalam membuat akta otentik dibidang pertanahan. Bertolak dari isu hukum itu, artikel ini ditulis dengan tujuan untuk mengetahui status kekuatan kepastian hukum Camat sebagai PPAT Sementara dan menawarkan konsep yang seharusnya dilaksanakan dalam pemangkuan jabatan PPAT Sementara. Hasil penelitian menunjukkan bahwa dalam Peraturan Pemerintah Nomor 24 Tahun 2016 terdapat ketidakpastian hukum dalam rumusan pasalnya sebagai akibat adanya kekaburan norma hukum atas penyelenggaraan jabatan PPAT Sementara. Kekaburan itu terlihat dari penunjukan PPAT Sementara kepada Camat, dimana Camat merupakan Pejabat Tata Usaha Negara yang bertentangan dengan aturan Jabatan PPAT yang melarang PPAT diselenggarakan oleh Pegawai Negeri Sipil. Seharusnya pengembanan PPAT Sementara itu dialihkan kepada kepala desa, dimana keberadaan kepala desa itu juga diakomodasi dalam ketentuan jabatan PPAT sebagai PPAT Sementara. Hal itu dianggap lebih memberikan kepastian hukum dan merupakan solusi ideal dalam pemangkuan PPAT Sementara. Oleh sebab itu, disarankan kepada pemangku
\end{abstract}


kepentingan dibidang pertanahan, khususnya di bidang PPAT agar dapat melakukan pengkajian atas gagasan ini untuk diimplementasikan terhadap pemangkuan jabatan PPAT Sementara di Indonesia.

Kata kunci: Camat; Pejabat Pembuat Akta Tanah Sementara; kepastian hukum

\section{Pendahuluan}

Setelah bangsa Indonesia merdeka pada tahun 1945, salah satu produk hukum yang fenomenal dan masih eksis hingga saat ini adalah Undang-Undang Pokok Agraria Nomor 5 Tahun 1960 (UUPA). Tujuan dasar lahirnya ketentuan hukum tersebut itu adalah untuk menghapus konsep pengelolaan "agraria kolonial" dan beralih ke konsep "agraria nasional". ${ }^{1}$ Dikatakan sebagai agraria nasional oleh karena ketentuan hukum tersebut telah menghapus konsepsi hukum agraria kolonial yang sangat merugikan bangsa Indonesia sebagai tuan di negeri sendiri. Oleh karena itu, dapat dikatakan bahwa UUPA itu merupakan salah satu produk hukum nasional yang lahir dari pemikiran anak bangsa yang bersumber dari hukum adat, di mana produk hukum itu dilahirkan, diarahkan dan didasarkan pada kerangka cita-cita atau nilai-nilai luhur bangsa dalam pengelolaan sumber agraria nasional untuk kemashalatan rakyat Indonesia.

Pemakaian istilah agraria nasional atau hukum agraria nasional itu adalah dikarenakan penulis cenderung mengikuti konsep berfikirnya C.G.F. Sunaryati Hartono dalam memandang istilah hukum positif dan hukum nasional. Beliau berpendapat bahwa terdapat perbedaan yang mendasar antara konsep hukum positif dan hukum nasional. Perbedaan konsep itu hadir oleh karena belum seluruh hukum positif Indonesia (ius constitutum), sudah merupakan hukum nasional yang didasarkan dan bernafaskan cita-cita bangsa. Masih ada hukum yang berlaku di Indonesia itu merupakan produk hukum warisan kolonial sebagai wujud pelaksanaan dari Pasal 1 Aturan Peralihan UUD NRI 1945. Lihat dalam C.G.F Sunaryati Hartono, "Membangun Budaya Hukum Pancasila Sebagai Bagian Dari Sistem Hukum Nasional Indonesia Di Abad 21", Jurnal Veritas Et Justitia, Vol. 1, No. 2, 2015, hal. 256.
Diantara materi pokok yang dikandung dalam aturan tentang agraria nasional itu adalah berhubungan dengan penguasaan hak atas tanah. Hal ini penting untuk diatur oleh negara dikarenakan di atas tanah itu melekat nilai-nilai strategis. Artinya, tanah bagi rakyat Indonesia bukan hanya bernilai ekonomis, melainkan juga sangat berhubungan dengan aspek sosial, budaya, bahkan keyakinan dari masyarakat itu $^{2}$ sehingga mewajibkan negara untuk mengatur dan memimpin penggunaan hingga peruntukkan tanah itu, yang semuanya itu dimuarakan sebesar-besarnya hanya demi kemakmuran rakyat Indonesia. Dengan kata lain, negara cukup menjadi regulator saja, bukan pelaku langsung. ${ }^{3}$ Oleh sebab itu, sangatlah diperlukan alasan-alasan yuridis yang bisa menegaskan bahwa sebuah tanah itu diakui negara telah dimiliki oleh subjek hukum tertentu, sehingga dalam pengelolaan tanah tersebut dibutuhkan perlakuan khusus untuk menghindari sengketa atau konflik pertanahan dikemudian hari.

Perlakuan khusus yang dimaksud itu adalah dengan memberikan status hak tertentu atas tanah melalui penyelenggaraan pendaftaran tanah. Hal ini dilakukan dengan tujuan untuk memberikan jaminan kepastian hukum atas tanah melalui pemberian tanda bukti kepemilikan hak atas tanah. Jaminan kepastian hukum yang hendak diwujudkan dalam pendaftaran tanah itu, meliputi kepastian status hak yang didaftar, kepastian subjek hak dan kepastian objek hak. ${ }^{4}$ Dalam proses pelaksanaan kegiatan pendaftaran tanah tersebut, Pejabat Pembuat Akta Tanah (PPAT) memiliki peran yang sangat penting dalam kegiatan pendaftaran tanah demi mencapai tujuan negara. PPAT merupakan salah satu pemangku jabatan umum yang ditunjuk oleh negara untuk melakukan proses pendaftaran tanah sebelum diteruskan pendaftarannya ke kantor pertanahan. Tugas

Sukirno, Politik Hukum Pengakuan Hak Ulayat, Jakarta: Kencana, 2018, hal. 1.

3 Jimly Assiddiqie, Konstitusi Ekonomi, Jakarta: Kompas, 2010, hal. 250

Urip Santoso, Hukum Agraria; Kajian Komprehensif, Jakarta: Kencana, 2014, hal. 278. 
utamanya adalah melaksanakan sebagian dari kegiatan pendaftaran tanah dengan membuat akta otentik di bidang pertanahan. ${ }^{5}$ Tujuannya tidak lain adalah dalam rangka pemeliharaan data yuridis pertanahan yang tersimpan dan disajikan di kantor pertanahan kabupaten/ kota, serta surat-surat tanda bukti selalu cocok dengan keadaan yang sebenarnya. ${ }^{6}$

Mengingat tugas dari pemangku jabatan PPAT tersebut, tentunyadalampenyelenggaraan jabatan PPAT itu tidak menutup kemungkinan terjadinya kekosongan PPAT di suatu kabupaten/kota sebagai akibat luasnya wilayah teritorial Negara Kesatuan Republik Indonesia (NKRI). Untuk menyikapi kondisi tersebut, para perumus ketentuan mengenai PPAT mengadakan dan/atau menunjuk pejabat lainnya untuk mengemban jabatan PPAT. Pejabat lain yang diberikan kewenangan untuk mengemban jabatan PPAT adalah Camat atau Kepala Desa, yang setelah mengangkat sumpah jabatan akan didaulat sebagai PPAT Sementara sebagaimana dimaksud dalam Pasal 5 Ayat (3) huruf a Peraturan Pemerintah Nomor 37 Tahun 1998 Tentang Pejabat Pembuat Akta Tanah.

Sehubungan dengan hal di atas, artikel ini ditulis sebagai wujud untuk menelaah kembali terkait penunjukan Camat sebagai PPAT Sementara. Hal ini didasari pada argumentasi bahwa jika dilihat secara cermat rumusan pasal dalam aturan jabatan PPAT, terdapat pertentangan norma antara jabatan PPAT dan jabatan Camat, di mana jabatan PPAT merupakan pemangku jabatan umum yang mempunyai tugas pokok melaksanakan sebagian kegiatan pendaftaran tanah dengan membuat akta sebagai bukti telah dilakukannya perbuatan hukum tertentu mengenai hak atas tanah atau hak milik atas satuan rumah susun, sementara Camat merupakan pejabat pemangku jabatan pemerintahan yang berstatus sebagai Aparatur Sipil Negara (Pegawai Negeri Sipil).

Khairulnas dan Leny Agustan, Panduan Notaris/PPAT dalam Menghadapi Gugatan Perdata, Yogyakarta: UII Press, 2018, hal. 17.

6 Boedi Harsono, "Tugas dan Kedudukan Pejabat Pembuat Akta Tanah”, Jurnal Hukum dan Pembangunan, Vol. 25, No 6, 1995, hal. 477 - 478 .
Adanya hal demikian itu telah menampakkan pertentangan norma dalam pelaksanaan jabatan PPAT sebagaimana dimaksud dalam ketentuan Pasal 7 ayat 2 huruf b Peraturan Pemerintah Nomor 24 Tahun 2016. Dengan sebab demikian, tujuan utama dari diadakannya artikel ini adalah untuk menganalisis mengenai pertentangan norma terkait jabatan Camat sebagai PPAT Sementara. Basis pemikiran utama artikel ini didasari pada munculnya diskrepansi norma menyangkut penunjukan Camat sebagai PPAT Sementara sehingga hal itu dianggap telah mencederai nilai kepastian hukum, di mana seharusnya nilai kepastian hukum itu juga merupakan salah satu tujuan hukum yang harus diwujudkan dalam sebuah aturan hukum positif.

Terhadap isu hukum di atas, ada beberapa artikel yang pernah membahas tentang Camat sebagai PPAT Sementara. Diantaranya adalah tulisan berjudul "Peran Camat Selaku Pejabat Pembuat Akta Tanah (PPAT) dalam Jual Beli Tanah" yang ditulis oleh Iga Gangga Santi Dewi. Tulisan ini difokuskan untuk mengetahui peran Camat sebagai PPAT, khususnya dalam jual-beli tanah dan upaya yang dilakukan dalam menanggulangi terjadinya jual beli tanah yang dilakukan di bawah tangan di Kabupaten Jepara. ${ }^{7}$ Namun hal yang menarik perhatian penulis dari tulisan tersebut adalah adanya statement yang menyebutkan bahwa Camat yang merangkap PPAT secara formal tidak melanggar ketentuan hukum yang berlaku, ${ }^{8}$ di mana hal ini merupakan isu hukum utama yang akan diulas dalam artikel ini. Selanjutnya terdapat juga tulisan dengan judul "Tugas dan Kewenangan Camat Sebagai PPAT Sementara Dalam Pembuatan Akta-Akta Tentang Tanah; Studi Di Kabupaten Boyolali” yang ditulis oleh Muhammad Munthohar dan Amin Purnawan. Tulisan ini difokuskan untuk mengetahui pelaksanaan tugas dan kewenangan Camat sebagai PPAT Sementara dalam pembuatan akta-akta tanah di Kabupaten Boyolali disertai

Iga Gangga Santi Dewi, "Peran Camat Selaku Pejabat Pembuat Akta Tanah (PPAT) dalam Jual Beli Tanah", Jurnal Pandecta, Vol. 5 No. 2, 2010, hal. 121.

Ibid., hal. 122. 
uraian-uraian tentang kendala-kendala yang hadapi Camat sebagai PPAT Sementara dan upaya yang dilakukan dalam mengatasi hambatan tersebut. ${ }^{9}$ Namun dalam tulisan ini juga memuat statement yang juga menarik perhatian penulis dengan menyebutkan bahwa tidak menjadi persoalan seorang Camat masih dapat menjabat sebagai PPAT Sementara meskipun di wilayahnya sudah ada NotarisPPAT sepanjang masih ada formasi PPAT ataupun Camat tersebut sebelumnya sudah menjabat PPAT Sementara di wilayah lain, ${ }^{10}$ padahal politik hukum diadakannya Camat sebagai PPAT Sementara adalah dalam rangka mengisi kekosongan PPAT di suatu kabupaten/ kota, sehingga hal itu menjadi inkonsisten. Kemudian ada juga artikel yang menyamakan konsep antara PPAT Sementara dengan PPAT sebagai pejabat umum sebagaimana dimuat dalam kesimpulan dari tulisan Hamzah dengan judul "Kedudukan Camat Selaku Pejabat Pembuat Akta Tanah Sementara."11 Sementara itu, ada juga beberapa tulisan lainnya yang bersinggungan dengan isu PPAT Sementara, akan tetapi tulisan itu dianggap tidak terlalu relevan untuk diuraikan disini meskipun isu hukum yang diangkat adalah menyangkut PPAT Sementara. ${ }^{12}$

Muhammad Munthohar dan Amin Purnawan, "Tugas Dan Kewenangan Camat Sebagai PPAT Sementara Dalam Pembuatan Akta-Akta Tentang Tanah; Studi Di Kabupaten Boyolali", Jurnal Akta, Vol. 4, No. 4, 2017, hal. 528.

10 Ibid., hal. 531.

11 Hamzah, "Kedudukan Camat Selaku Pejabat Pembuat Akta Tanah Sementara”, Jurnal Transformasi Administrasi, Vol. 9 No. 2, 2019, hal. 225.

12 Artikelnya seperti dalam Ricki Yoan, Amzulian Rifai dan Amin Mansyur, "Tanggung Jawab Camat Selaku Pejabat Pembuat Akta Tanah Sementara Setelah Tidak Menjabat Lagi Terhadap Akta Yang Dibuatnya", Repertorium: Jurnal Ilmiah Hukum Kenotariatan, Vol. 6 No. 2, 2017. Djumardin dan RR.Cahyowati, "Kewenangan Camat Dan Kepala Desa Sebagai Pejabat Pembuat Akta Tanah (PPAT) Setelah Berlakunya UUJN", Jurnal Notariil, Vol. 2, No. 2, 2017. Vuji Ervina, "Pelayanan Pendaftaran Tanah Oleh Camat Sebagai Pejabat Pembuat Akta Tanah (PPAT) Sementara Di Kantor Kecamatan Dusun Selatan Kabupaten Barito Selatan”, Jurnal Ilmu Politik dan Pemerintahan Lokal, Vol. 2, No. 2, 2013. Nur Oloan, "Praktek Pembuatan Akta Tanah oleh Camat dalam Kedudukan dan Fungsinya Selaku PPAT Sementara di
Selanjutnya perlu juga untuk dipahami bahwa artikel ini bukanlah ditulis sebagai bentuk penolakan penulis terhadap eksistensi PPAT Sementara, namun artikel ini khusus ditulis untuk mengulas pertentangan norma hukum dalam pemangkuan jabatan PPAT Sementara. Dengan alasan itu, maka artikel ini ditulis sebagai upaya untuk menjawab 2 (dua) persoalan utama, yaitu: 1) Bagaimana kekuatan kepastian hukum Camat sebagai PPAT Sementara yang ditunjuk berdasarkan Peraturan Pemerintah Nomor 37 Tahun 1998 jo. Peraturan Pemerintah Nomor 24 Tahun 2016?; 2) Bagaimana seharusnya pemangkuan jabatan PPAT-Sementara itu dilaksanakan ke depannya? Tujuan yang hendak dicapai dari perumusan masalah itu adalah untuk mengetahui status kekuatan kepastian hukum Camat sebagai PPAT Sementara dan menawarkan konsep yang seharusnya dilaksanakan dalam pemangkuan jabatan PPAT Sementara.

\section{Metode Penelitian}

Penelitian ini termasuk ke dalam tipologi penelitian hukum normatif. Penelitian jenis ini berfungsi untuk memberi argumentasi yuridis ketika terjadi kekosongan, kekaburan dan konflik norma. ${ }^{13}$ Penelitian jenis ini akan ditelaah dengan menggunakan bahan hukum primer yang meliputi segala peraturan perundang-undangan yang berkaitan dengan tugas jabatan PPAT dan bahan hukum sekunder, yang meliputi segala buku dan artikel ilmiah yang besinggungan dengan pekerjaan PPAT. Sementara untuk teknik pengumpulan bahan hukum itu dilakukan dengan studi kepustakaan yang didukung dengan bahanbahan yang authoratif dengan menggunakan pendekatan perundang-undangan, pendekatan

Kota Padang Sidimpuan", Jurnal Pendidikan Ilmu-Ilmu Sosial, Vol. 8, No. 2, 2016. Gusti Surya Hadi Saputra, "Batasan Waktu Sementara Terhadap Camat Sebagai PPAT Sementara", Calyptra; Jurnal Mahasiswa Universitas Surabaya, Vol. 3 No. 1, 2014.

13 I Made Pasek Diantha, Metodologi Penelitian Hukum Normatif dalam Justifikasi Teori Hukum, Jakarta: Kencana, 2019, hal. 12 . 
konsep dan pendekatan sejarah melalui analisis hukum yang deskriptif-evaluatif.

\section{Diskrepansi Jabatan atas Status Camat sebagai PPAT Sementara}

Di era modern sekarang ini, semua negara berdaulat di dunia memiliki tujuan utama adalah untuk mensejahterakan rakyatnya. Tidak ada satu pun negara yang memiliki tujuan untuk menyengsarakan rakyatnya. Hanya negara yang diselenggarakan oleh seorang diktator saja yang cenderung menyusahkan kehidupan rakyatnya. Oleh sebab itu, dengan adanya kewajiban negara untuk menyejahterakan rakyatnya tersebut, maka kekuasaan yang dimiliki itu harus dibatasi oleh hukum agar tidak memberikan dampak negatif dalam lalu lintas kehidupan berbangsa dan bernegara. Dengan demikian, agar tujuan penyelenggaraan negara itu dapat terlaksana dengan baik dan benar, maka hukum mempunyai fungsi yang sangat penting, yakni memberikan parameter yang jelas atas tindakan yang boleh dan dilarang dilaksanakan oleh penyelenggara kekuasaan negara. Disamping itu, Sri Redjeki Hartono berpendapat bahwa hukum itu juga harus mampu menjaga dan mengatur harkat, martabat manusia serta kehidupan kemanusiaan dengan mengatur keseimbangan kepentingan semua pihak demi kesejahteraan nilai-nilai kemanusiaan. ${ }^{14} \mathrm{Hal}$ demikian itu penting untuk dilaksanakan oleh karena suatu kekuasaan yang diberikan itu cenderung korup dan kekuasaan absolut itu korup secara mutlak sebagaimana pernah diutarakan oleh Lord Acton. Maka dari itu, dibutuhkan suatu norma hukum yang tepat dan jelas sebagai alat untuk membatasi serta mengendalikan eksistensi pemegang kekuasaan agar tidak bertindak di luar kewenangannya (abuse of power) demi kesejahteraan nilai-nilai kemanusiaan.

Secarasosiologis, kekuasaan (macht, pouvoir) itu merupakan kemampuan untuk memengaruhi pihak lain agar mengikuti kehendak pemegang kekuasaan, baik secara sukarela maupun

$14 \quad$ Sri Redjeki Hartono, "Perspektif Hukum Bisnis pada Era Teknologi”, Pidato Pengukuhan Jabatan Guru Besar Hukum Dagang pada Fakulas Hukum Universitas Diponegoro, Kampus UNDIP-Semarang, 18 Desember 1995, hal. 10. dengan terpaksa. ${ }^{15}$ Sebagai akibat adanya kekuasaan itu, maka pemilik kekuasaan akan memiliki berbagai kewenangan dan wewenang untuk melaksanakan kekuasaannya. Dalam hal ini, meskipun konsep kewenangan sering dipergunakan silih berganti dengan wewenang, namun SF Marbun membedakan antara kedua istilah itu. Menurutnya, kewenangan (authority, gezag) merupakan kekuasaan yang diformalkan baik terhadap segolongan orang tertentu, maupun kekuasaan terhadap suatu bidang pemerintahan tertentu secara bulat yang berasal dari kekuasaaan legislatif maupun dari kekuasaan pemerintah, sedangkan wewenang (competence,bevoegdheid) hanya mengenai sesuatu onderdil tertentu atau bidang tertentu saja. Dengan demikian, kewenangan merupakan kumpulan dari wewenang-wewenang (rechtsbevoegdheden). ${ }^{16}$ Selain itu, Undang-Undang Nomor 30 Tahun 2014 tentang Administrasi Pemerintahan juga membedakan antara konsep wewenang dan kewenangan. Pasal 1 angka 5 UndangUndang tersebut mendefenisikan wewenang sebagai hak yang dimiliki oleh Badan dan/ atau Pejabat Pemerintahan atau penyelenggara negara lainnya untuk mengambil keputusan dan/atau tindakan dalam penyelenggaraan pemerintahan. Sementara dalam Pasal 1 angka 6 mendefenisikan Kewenangan sebagai kekuasaan Badan dan/atau Pejabat Pemerintahan atau penyelenggara negara lainnya untuk bertindak dalam ranah hukum publik. Sebagai akibat wewenang itu merupakan bagian penting dalam Hukum Administrasi Negara, maka wewenang itu dapat diperoleh atau diberikan oleh negara melalui tiga sumber, yakni melalui atribusi, delegasi dan mandat. Wewenang yang diperoleh secara atribusi merupakan wewenang yang bersifat asli yang langsung atau berasal dari peraturan perundang-undangan. Kemudian delegasi itu merupakan wewenang yang diperoleh dari pelimpahan wewenang dari pejabat yang satu ke pejabat lainnya.

\footnotetext{
15 SF Marbun, Hukum Administrasi Negara I, Yogyakarta: FH UII Press, 2018, hal. 166.

$16 \quad$ Ibid, hal. 177.
} 
Sementara mandat merupakan wewenang yang hanya bertindak untuk dan atas nama pemberi mandat. ${ }^{17}$

Berdasarkan uraian sebelumnya itu, PPAT merupakan sebuah jabatan umum yang kewenangannya diperoleh langsung melalui jalan atribusi. Kewenangan itu diberikan oleh kekuasaan hukum dalam rangka untuk bertindak "membantu" Kepala Kantor Pertanahan dalam membuat akta-akta otentik mengenai perbuatan hukum mengenai Hak Atas Tanah atau Hak Milik Atas Satuan Rumah Susun dengan dasar aturan hukum berupa Peraturan Pemerintah Nomor 37 Tahun 1998 sebagaimana telah diubah dengan Peraturan Pemerintah Nomor 24 Tahun 2016. Namun harus dipahami pula bahwa konsep membantu tersebut bukanlah dimaksudkan sebagai bentuk penundukan PPAT sebagai pegawai dari kantor pertanahan, akan tetapi konsep membantu itu dapat diartikan sebagai bentuk membirokratisasikan ${ }^{18}$ akta-akta otentik menyangkut Hak Atas Tanah atau Hak Milik Atas Satuan Rumah Susun dengan model pekerjaan yang mengedepankan prinsip kehatihatian, ${ }^{19}$ profesional dan integritas dalam bekerja. Tujuannya adalah untuk memudahkan kantor pertanahan dalam memverikasikasi dan memvaliditasi tanah dalam lalu lintas peralihan Hak Atas Tanah atau Hak Milik Atas Satuan Rumah Susun.

17 Ridwan HR, Hukum Administrasi Negara Ed. Revisi, Jakarta: Rajawali Pers, 2017, hal. 105.

18 Terinspirasi dari pendapat Satjipto Rahardjo yang menyatakan bahwa jabatan notaris itu erat kaitannya dengan birokratisasi masyarakat. Lihat dalam Satjipto Rahardjo, "Peranan Notaris Sebagai Pembuat Akta Dalam Masa Pembangunan”, Makalah, Simposium Fungsi Notaris dalam Pembangunan, Program Pendidikan Kenotariatan, Fakultas Hukum Universitas Diponegoro, Semarang pada tanggal 29 Mei 1984, hal. 2.

19 Lihat dalam Hatta Isnaini Wahyu Utomo dan Hendry Dwicahyo Wanda, "Prinsip Kehati-Hatian Pejabat Pembuat Akta Tanah dalam Peralihan Tanah yang Belum Bersertifikat", Jurnal Hukum Ius Quia Iustum, Vol. 24, No. 3, 2017, hal. 467-487. Lihat juga Hendry Dwicahyo Wanda, "Prinsip Kehati-hatian Pejabat Pembuat Akta Tanah dalam Pengurusan Peralihan Tanah "Letter C", Jurnal Masalah-Masalah Hukum, Vol. 46 No. 2, 2017, hal. 112-124.
Sebagai akibat adanya pemahaman seperti itu, maka dengan adanya suatu kemampuan untuk bertindak yang diberikan oleh kekuasaan hukum, maka setiap tindakan tersebut haruslah dilandasi pada wewenang yang sah, prosedur yang tepat dan substansi yang jelas juga. ${ }^{20} \mathrm{Hal}$ ini berlaku juga bagi pengemban jabatan PPAT, di mana dengan berlakunya Peraturan Pemerintah Nomor 37 Tahun 1998 sebagaimana telah diubah dengan Peraturan Pemerintah Nomor 24 Tahun 2016 sebagai tindak lanjut dari Peraturan Pemerintah Nomor 24 Tahun 1997, maka PPAT sebagai jabatan umum memiliki landasan hukum yang kuat dan sah dalam bertindak sesuai dengan kewenangannya. Namun yang menjadi persoalannya adalah masih adanya substansi yang tidak jelas dalam pelaksanaan jabatan PPAT, sehingga memunculkan kewajiban untuk menguji kembali legalitas dan keabsahan suatu tindakan dalam melaksanakan tugas-tugasnya itu, yaitu dengan peraturan perundang-undangan dan asas-asas pemerintahan yang baik. ${ }^{21}$ Apabila dalam pengujian itu tidak sejalan dengan peraturan perundang-undangan yang berlaku, maka kekuasaan hukum yang diberikan itu adalah menyalahi asas kepastian hukum dan asas ini juga merupakan salah satu asas dalam asas-asas pemerintahan yang baik. Hal demikian ini penting juga untuk dipertimbangkan oleh karena bagi negara yang lahir dari tradisi berpikir civil law, konsep kepastian hukum itu melandasi penyelenggaraan negara hukum (rechtsstaat) yang selanjutnya menghasilkan sistem yang dikenal sebagai separation of power dalam penyelenggaraan negara. ${ }^{22}$

Dalam konteks sistem hukum Indonesia, Mahfud MD mengatakan bahwa negara hukum Indonesia yang berdasarkan Pancasila dan Undang-Undang Dasar Negara Republik Indonesia Tahun 1945 mengambil konsep prismatik atau integratif dari 2 (dua) konsepsi

Philipus M Hadjon (et.all), Hukum Administrasi dan Tindak Pidana Korupsi, Yogyakarta: Gadjah Mada University Press, 2012, hal. 7.

$21 \quad$ Ibid

22 FX Adji Samekto, Hukum dalam Lintasan Sejarah, Bandar Lampung: Indept Publishing, 2013, hal. 4. 
negara hukum di dunia, berupa konsep the rule of law dan rechtstaat, sehingga prinsip kepastian hukum dalam rechtsstaat dipadukan dengan prinsip keadilan dalam the rule of law. ${ }^{23}$ Kendati memakai konsep prismatik, namun dominasi konsep civil law masih sangat kental dirasakan di Indonesia hingga saat ini. Dominasi itu dapat dilihat dari bengkaknya jumlah regulasi yang hadir di dalam kita berdemokrasi, sehingga telah menjadikan "nilai jual" aturan tertulis itu sangat terasa dalam penyelenggaraan negara dan juga mendapatkan tempat utama dalam sistem penegakan hukum di Indonesia. Mengapa demikian? Hal itu terjadi oleh karena di dalam sebuah negara yang cenderung dipengaruhi oleh sistem civil law, keberadaan aturan hukum tertulis merupakan salah satu wujud pembentukan negara hukum untuk mencapai keadilan hukum. Konsep keadilan hukum itu dapat dimaknai sebagai sebuah upaya melahirkan tertib hukum melalui pembentukan aturan hukum demi mencapai tujuan kepastian hukum. Dengan kata lain, keadilan tidak akan terwujud jika tidak ada kepastian hukum dan kepastian hukum tidak akan nyata jika hukum gagal berfungsi sebagai pengatur ketertiban masyarakat. ${ }^{24}$ Oleh sebab itu, dijadikannya nilai kepastian hukum sebagai tujuan hukum utama dalam artikel ini adalah didasarkan pada asas prioritas yang kasuistis dalam memahami isu hukum. Asas itu mengajarkan bahwa dari ketiga tujuan hukum (keadilan, kepastian dan kemanfaatan hukum) harus diprioritaskan sesuai dengan kasus yang sedang dialami atau akan dipelajari oleh peneliti hukum. ${ }^{25}$

Kendati asas prioritas itu lebih didahulukan kepada nilai kepastian hukum, bukan berarti pilihan itu telah menggeser nilai keadilan di dalamnya, namun nilai kepastian itu tentunya memiliki parameter yang harus

23 Moh. Mahfud MD, Membangun Politik Hukum, Menegakkan Konstitusi, Jakarta: Rajawali Pers, 2012, hal. 26.

24 Romli Atmasasmita, Teori Hukum Integratif; Rekonstruksi Terhadap Teori Hukum Pembangunan dan Teori Hukum Progresif, Yogyakarta: Genta Publishing, 2012, hal. 12.

25 Marwan Mas, Pengantar Ilmu Hukum, Bogor: Ghalia Indonesia, 2014, hal. 85. selalu dipertimbangkan, yakni kepastian yang berkeadilan. Dengan demikian, posisi kepastian hukum itu dapat dipahami sebagai sebuah terminologi yang tidak saling berlawanan dengan kepastian hukum. Sidharta ${ }^{26}$ memisalkan pada terminologi keadilan prosedural sebagaimana diistilahkan oleh Nonet dan Selznick untuk menyebutkan salah satu indikator dari tipe hukum otonom. Ternyata setelah diamati bermuara pada kepastian hukum demi tegaknya the rule of law. Jadi, dalam konteks ini keadilan dan kepastian hukum tidaklah berseberangan, melainkan justru bersandingan.

Konsep kepastian hukum itu bisa dimaknai dalam berbagai macam kebutuhan. Hal ini terjadi oleh karena kebutuhan untuk memberikan kepastian dalam suatu masalah hukum akan berbeda-beda. Namun pastinya, kepastian itu dibutuhkan untuk menghilangkan keragu-raguan. ${ }^{27}$ Kepastian hukum itu adalah syarat mutlak untuk bisa dikehendakinya supaya hukum dapat menjalankan tugasnya dengan sebaik-baiknya dan keadilan dijadikan pedoman bagi kebenaran isi hukum, sehingga kedua-duanya dibutuhkan agar hukum dapat menyelenggarakan tugasnya dengan baik serta dapat mencapai maksudnya. ${ }^{28}$ Dalam hal itu, Satjipto Rahardjo melihat kepastian hukum itu sebagai suatu keadaan yang memenuhi tuntutan serta kebutuhan yang sangat praktis, yaitu adanya kaidah tertentu. Jadi dalam konteks tuntutan yang sangat praktis tersebut, yang dikehendaki adalah adanya peraturan hukum..$^{29}$ Budiman Ginting memandang kepastian hukum itu sebagai konsistensi peraturan itu ditunjukkan dengan adanya peraturan yang

26 Sidharta, Putusan Hakim; Antara Keadilan, Kepastian Hukum dan Kemanfaatan, dalam Bunga Rampai Komisi Yudisial, Reformasi Peradilan dan Tanggung Jawab Negara, Jakarta: Komisi Yudisial Republik Indonesia, 2010, hal. 3.

27 Maria S.W. Sumardjono dan Martin Samosir, Hukum Pertanahan dalam Berbagai Aspek, Medan: Bina Media, 2000, hal. 37.

28 Soedjono Dirdjosisworo, Pengantar Ilmu Hukum, Jakarta: Rajawali Pers, 2016, hal. 15.

29 Satjipto Rahardjo, "Meningkatkan Kepastian Hukum dalam Rangka Pelaksanaan Keadilan Berdasarkan Pancasila”, Jurnal Hukum dan Pembangunan, Vol. 18, No. 6, 1988, hal. 533-534. 
tidak saling bertentangan antara satu peraturan dengan peraturan yang lain, dan dapat dijadikan pedoman untuk suatu jangka waktu yang cukup, sehingga tidak terkesan setiap pergantian pejabat selalu diikuti pergantian peraturan yang bisa saling bertentangan. ${ }^{30}$ Disamping itu, Peter Mahmud Marzuki memaparkan bahwa kepastian hukum itu mengandung 2 (dua) pengertian, yaitu ${ }^{31}$ :

a. adanya aturan yang bersifat umum membuat individu mengetahui perbuatan apa yang boleh atau tidak boleh dilakukan.

b. berupa keamanan hukum bagi individu dari kesewenangan pemerintah karena dengan adanya aturan yang bersifat umum itu individu dapat mengetahui apa saja yang boleh dibebankan atau dilakukan oleh negara terhadap individu. Kepastian hukum bukan hanya berupa pasal-pasal dalam undang-undang melainkan juga adanya konsistensi dalam putusan hakim lainya untuk kasus yang serupa yang telah diputuskan.

Melangkah dari tinjauan mengenai konsep kepastian hukum tersebut, maka secara sederhana kepastian hukum itu dapat dipahami sebagai adanya kesingkronan dan tidak saling tumpang tindih antar peraturan perundangundangan. Dalam hal ini, sebagaimana telah diketahui bahwa dengan banyaknya jumlah peraturan perundang-undangan di Indonesia telah mengakibatkan banyaknya norma yang tidak konsisten terhadap norma lainnya, baik secara horizontal maupun vertikal. Bahkan ada juga pertentangan antar norma dalam satu ketentuan hukum. Oleh sebab itu, dibutuhkan penataan norma hukum agar adanya koherensi antar norma demi tercapainya tujuan hukum, termasuk juga aturan mengenai ke-PPAT-an.

Peraturan Pemerintah Nomor 37 Tahun 1998 sebagaimana telah diubah

30 Budiman Ginting, "Kepastian Hukum dan Implikasinya Terhadap Pertumbuhan Investasi di Indonesia”, Naskah Pidato Pengukuhan Jabatan Guru Besar Tetap dalam Bidang Hukum Investasi pada Fakultas Hukum Universitas Sumatera Utara, Medan, Universitas Sumatera Utara, 2008, hal. 2.

31 Peter Mahmud Marzuki, Pengantar Ilmu Hukum, Edisi Revisi, Cet ke-5, Jakarta: Kencana, 2013, hal. 137. dengan Peraturan Pemerintah Nomor 24 Tahun 2016 merupakan hukum positif bagi pemangku jabatan PPAT, namun sebelum diundangkannya kedua Peraturan Pemerintah itu, pelaksanaan tugas jabatan PPAT merujuk pada Peraturan Pemerintah Nomor 10 Tahun 1961 tentang Pendaftaran Tanah dan Peraturan Menteri Agraria Nomor 10 Tahun 1961 tentang Penunjukan Pejabat yang dimaksudkan dalam Pasal 19 Peraturan Pemerintah Nomor 10 Tahun 1961 tentang Pendaftaran Tanah. Kemudian seiring dengan penjalanan ketatanegaraan Indonesia, setelah berlakunya Peraturan Pemerintah Nomor 24 Tahun 1997 tentang Pendaftaran Tanah, maka Peraturan Pemerintah Nomor 10 Tahun 1961 tentang Pendaftaran Tanah itu pun dinyatakan tidak berlaku lagi. Oleh karena itu, dapat dikatakan bahwa Peraturan Pemerintah Nomor 24 Tahun 1997 tentang Pendaftaran Tanah merupakan landasan hukum utama hingga munculnya Peraturan Pemerintah Nomor 37 Tahun 1998 jo. Peraturan Pemerintah Nomor 24 Tahun 2016.

PPAT dalam Peraturan Pemerintah tersebut merupakan salah satu pejabat umum yang mempunyai tugas untuk membantu Kepala Kantor Pertahanan dalam melaksanakan kegiatan-kegiatan pendaftaran tanah tertentu menurut Peraturan Pemerintah Nomor 24 Tahun 1997 dan peraturan perundang-undangan yang terkait lainnya. Dalam mewujudkan hal demikian itu, hadirnya Peraturan Pemerintah itu adalah sebagai bentuk legalitas bertindak para PPAT dalam melaksanakan kewenangannya sebagai pejabat umum. Dalam hal itu, merujuk pada ketentuan Pasal 1 ayat (1) Peraturan Pemerintah Nomor 24 Tahun 2016, PPAT didefenisikan sebagai pejabat umum yang diberi kewenangan untuk membuat akta-akta otentik mengenai perbuatan hukum tertentu mengenai Hak Atas Tanah atau Hak Milik Atas Satuan Rumah Susun. Menilik pada konsep hukum tersebut, diantara unsur penting yang dikandung didalam defenisi itu adalah status khusus yang dimiliki oleh PPAT sekarang ini yang berbeda dengan 
konsep PPAT pada zaman dahulu. Sekarang ini, PPAT itu dilihat sebagai pejabat umum. Boedi Harsono menjelaskan bahwa pejabat umum itu merupakan seseorang yang diangkat oleh Pemerintah dengan tugas dan kewenangan memberikan pelayanan kepada umum di bidang tertentu. ${ }^{32}$ Oleh karena sekarang ini PPAT disetujui sebagai pejabat umum, J. Kartini Soedjendro menegaskan bahwa PPAT dan Notaris itu mempunyai posisi sederajat, di mana sebelum berlakunya UU Nomor 4 Tahun 1996 dan Peraturan Pemerintah Nomor 38 Tahun 1998, jabatan PPAT terkesan sebagai "jabatan ikutan" notaris. Namun setelah lahirnya kedua ketentuan tersebut, kedua jabatan itu memiliki posisi yang sama, ${ }^{33}$ meskipun lazimnya pemangku jabatan PPAT itu juga menjabat sebagai notaris, namun bukan berarti PPAT sudah pasti notaris, maupun sebaliknya. Namun ada juga yang melihat PPAT itu termasuk sebagai kategori Pejabat Tata Usaha Negara, sehingga Jabatan PPAT itu dapat diajukan sebagai tergugat ke Peradilan Tata Usaha Negara sebagaimana dimaksud dalam Pasal 1 angka 8 Undang-Undang Nomor 5 Tahun 1986 tentang Peradilan Tata Usaha Negara. ${ }^{34}$ Disamping itu, Habib Adji dengan merujuk pada Yurisprudensi Mahkamah Agung (Putusan Mahkamah Agung Nomor 62 K/TUN/1988 dan Putusan Mahkamah Agung Nomor 302 K/TUN/1999) memberikan beberapa karakteristik yuridis dari seorang PPAT, berupa ${ }^{35}$ :

a. PPAT sebagai Pejabat Tata Usaha Negara, karena menjalankan sebagian urusan pemerintah dalam bidang pertanahan atau dalam bidang pendaftaran tanah dengan

32 Boedi Harsono, "PPAT Sejarah, Tugas Kewenangannya", Majalah Renvoi, Nomor 844. IV, 2007, hal. 11.

33 J. Kartini Soedjendro, Perjanjian Peralihan Hak atas Tanah yang Berpotensi Konflik, Cet. ke-5, Yogyakarta: Kanisius, 2005, hal. 92-93.

34 Bambang Yunarko, "Kedudukan Jabatan dan Akta Pejabat Pembuat Akta Tanah dalam Sengketa di Peradilan Tata Usaha Negara”, Jurnal Perspektif, Vol. XVIII, No. 3, 2013, hal. 193-194.

35 Habib Adji, Beda Karakter Yuridis Antara Notaris dan PPAT Serta Akta Notaris-PPAT, dalam Satya Arinanto dan Ninuk Triyanti (Ed), Memahami Hukum: Dari Konstruksi Sampai Implementasi, Jakarta: Rajawali Press, 2012, hal. 547 membuat akta PPAT sesuai dengan aturan hukum yang berlaku;

b. Dalam kedudukannya sebagai Pejabat Tata Usaha Negara, PPAT tetap bertindak sebagai pejabat umum dalam bidang hukum perdata.

Selanjutnya Salim HS mengemukakan bahwa PPAT sebagai pejabat umum mempunyai legitimasi yang sangat kuat karena telah mendapatkan pengakuan, baik secara filosofis, yuridis maupun sosiologis. Dikatakan mendapatkan pengakuan secara filosofis oleh karena keberadaan jabatan PPAT adalah dalam rangka memberikan pelayanan kepada masyarakat, sehingga dengan adanya pelayanan itu, masyarakat akan mendapatkan kepastian hukum dan perlindungan hukum. Kemudian, dikatakan pengakuan secara yuridis dikarenakan keberadaan PPAT telah diatur di dalam berbagai peraturan perundang-undangan; dan sementara diakui secara sosiologis oleh sebab PPAT mendapat pengakuan dari masyarakat dikarenakan keberadaan jabatan PPAT sangat membantu masyarakat di dalam melakukan perubahan atau peralihan hak atas tanah, baik melalui jual beli, sewa menyewa, hibah maupun perbuatan-perbuatan hukum lainnya. ${ }^{36}$

Kendati demikian, kewenangan PPAT untuk membuat akta otentik menyangkut perbuatan hukum tertentu mengenai Hak Atas Tanah dan Hak Milik Atas Satuan Rumah Susun masih menemui keragu-raguan. Hal ini terjadi sebagai akibat suatu akta otentik itu haruslah telah memenuhi unsur Pasal 1868 KUH-Perdata, yang berbunyi bahwa akta otentik ialah suatu akta yang dibuat dalam bentuk yang ditentukan undang-undang oleh atau dihadapan pejabat umum yang berwenang untuk itu ditempat akta itu dibuat. Melalui defenisi akta otentik dalam pasal tersebut, dapat diperoleh unsur-unsur pasal yang harus dipenuhi untuk dikatakan sebagai akta otentik itu berupa :

a. bentuk akta ditentukan oleh undangundang;

\footnotetext{
36 Salim HS, Teknik Pembuatan Akta Pejabat Pembuat Akta Tanah, Jakarta: Rajawali Pers, 2016, hal 90-92.
} 
b. akta dibuat oleh atau dihadapan pejabat umum;

c. akta itu dibuat ditempat dimana akta itu dibuat.

Memperhatikan unsur-unsur dari Pasal 1868 KUH-Perdata itu, dapat dipahami bahwa akta otentik yang dibuat oleh PPAT itu tidaklah memenuhi unsur pasal tersebut. Hal ini dipengaruhi oleh landasan hukum kewenangan pembuatan akta otentik oleh PPAT itu diatur dalam Peraturan Pemerintah, sementara untuk dikatakan sebagai akta otentik haruslah bentuk akta itu berada dibawah payung sebuah undang-undang. Bahkan Habib Adji dengan tegas menyatakan bahwa akta PPAT itu bukan sebagai akta otentik melainkan sebagai perjanjian biasa setingkat dengan akta dibawah tangan. ${ }^{37}$ Hal demikian itu juga didasari dan sejalan dengan hierarki peraturan perundangundangan, bahwa Peraturan Pemerintah itu berada dibawah undang-undang dan kekuatan hukum keberlakuannya pun juga ditentukan berdasarkan urutan hierarki peraturan perundang-undangan tersebut (Pasal 7 ayat (1) dan (2) Undang-Undang Nomor 12 Tahun 2011 tentang Pembentukan Peraturan PerundangUndangan).

Terlepas dari perdebatan mengenai akta PPAT sebagai akta otentik, umumnya akta PPAT itu juga diakui sebagai akta otentik. Diakuinya akta PPAT sebagai akta otentik telah mengakibatkan akta PPAT tersebut mempunyai nilai kekuatan pembuktian yang sempurna dan mengikat. Lilik Mulyadi ${ }^{38}$ menjelaskan bahwa pengertian "sempurna" itu dikarenakan akta tersebut cukup membuktikan tentang peristiwa atau hak. Konkretnya, sebagai bukti sempurna dalam arti bahwa ia tidak memerlukan penambahan alat bukti lagi. Sedangkan "mengikat" dimaksudkan bahwa apa yang ditulis dalam akta tersebut harus dipercaya hakim, yakni harus dianggap

\footnotetext{
37 Habib Adji, Meneropong Khazanah Notaris dan PPAT Indonesia, Jakarta: PT Citra Aditya Bakti, 2009, hal. 274.

38 Lilik Mulyadi, Seraut Wajah Putusan Hakim dalam Hukum Acara Perdata Indonesia, Bandung: PT Citra Aditya Bakti, 2015, hal. 94.
}

sebagai benar selama ketidakbenaran tersebut tidak dibuktikan sebaliknya. Dengan sebab demikian, PPAT sebagai pejabat umum merupakan seseorang yang diangkat dan diberhentikan oleh Pemerintah setelah memenuhi persyaratan tertentu yang ditetapkan oleh peraturan perundang-undangan untuk menduduki jabatan tertentu dan diberikan kewenangan memberikan pelayanan umum kepada masyarakat yang melakukan perbuatan hukum tertentu mengenai Hak Atas Tanah atau Hak Milik Atas Satuan Rumah Susun. ${ }^{39}$ Kewenangan untuk membuat akta sebagai bukti telah dilakukannya perbuatan hukum tertentu mengenai Hak Atas Tanah atau Hak Milik Atas Satuan Rumah Susun itu adalah akan dijadikan dasar untuk pendaftaran perubahan data pendaftaran tanah yang diakibatkan oleh perbuatan hukum itu. Dalam hal ini, perbuatan hukum yang dimaksudkan itu adalah berhubungan dengan jual beli; tukar menukar; hibah; pemasukan ke dalam perusahaan (inbreng); pembagian hak bersama; pemberian Hak Guna Bangunan/Hak Pakai atas Tanah Hak Milik; pemberian Hak Tanggungan; dan Pemberian Kuasa Membebankan Hak Tanggungan.

Dalam melaksanakan kewenangannya itu, Peraturan Pemerintah Nomor Nomor 24 Tahun 2016 telah menggolongkan pemangku jabatan PPAT ke dalam 3 (tiga) golongan, yakni: Pertama, PPAT sebagai pejabat umum, yakni pengangkatan PPAT dilaksanakan apabila telah memenuhi segala persyaratan yuridisformal sebagaimana dimaksud dalam segala peraturan perudang-undangan yang berlaku. Kedua, PPAT sebagai pejabat pemerintah, yakni pejabat yang memangku jabatan PPAT yang berlatar belakang dari pejabat pemerintah yang ditunjuk oleh Menteri dengan wilayah kerja meliputi wilayah kerjanya sebagai pejabat pemerintah yang menjadi dasar penunjukananya dan tentunya tanpa perlu memenuhi persyaratan formil sebagaimana dimaksudkan

\footnotetext{
39 Urip Santoso, Pejabat Pembuat Akta Tanah; Perspektif Regulasi, Wewenang dan Sifat Akta, Jakarta: Kencana, 2016, hal. 62-63.
} 
sebelumnya; Ketiga, PPAT sebagai pejabat badan, yakni pejabat yang ditunjuk karena jabatannya untuk melaksanakan tugas PPAT dengan membuat akta PPAT tertentu khusus dalam rangka pelaksanaan program atau tugas pemerintah tertentu. Memperhatikan golongan dari PPAT tersebut, maka perlu dicermati lagi terkait dengan PPAT yang dijabat oleh pejabat pemerintah. PPAT jenis ini merupakan pejabat yang ditunjuk oleh karena jabatannya untuk melaksanakan tugas PPAT melalui pembuatan akta PPAT di daerah yang belum cukup terdapat PPAT. Menurut Salim HS, munculnya daerahdaerah yang belum cukup PPAT itu adalah dikarenakan oleh pemilihan wilayah kerja yang paling banyak dimohonkan, baik calon PPAT maupun perpindahan PPAT yang lama adalah di wilayah perkotaan, sedangkan untuk wilayah yang berada di pedesaan adalah sangat sedikit yang mengajukan permohonan penempatan kerja, sehingga menyebabkan di wilayah ini menjadi belum cukup terdapat PPAT. Dengan alasan itu, di daerah pedesaaan tersebut perlu diangkat PPAT Sementara. ${ }^{40}$

Menurut ketentuan hukum tentang PPAT, pejabat pemerintah yang dimaksudkan untuk menjabat PPAT Sementara itu adalah Camat atau Kepala Desa. Namun terhadap kedua jenis pejabat pemerintah itu, hanya Camat sebagai pemangku jabatan PPAT Sementara yang patut untuk dikaji ulang. Adanya keinginan untuk mengkaji kembali terkait Camat sebagai PPAT Sementara adalah dikarenakan status Camat sebagai pejabat pemerintah dengan status sebagai Pegawai Negeri Sipil (Aparatur Sipil Negara). Hal ini dapat diketemukan didalam ketentuan Pasal 224 Undang-Undang Nomor 23 Tahun 2014, yang menyebutkan bahwa Kecamatan dipimpin oleh seorang Kepala Kecamatan yang disebut Camat yang berada dibawah dan bertanggung jawab kepada Bupati/Walikota melalui sekretaris daerah. Dalam hal demikian itu, Bupati/Walikota wajib mengangkat Camat dari Pegawai Negeri Sipil yang menguasai

\footnotetext{
40 Salim HS, Peraturan Jabatan dan Kode Etik Pejabat Pembuat Akta Tanah (PPAT), Jakarta: Rajawali Pers, 2019, hal. 139-140.
}

pengetahuan teknis pemerintahan dan memenuhi persyaratan kepegawaian sesuai dengan ketentuan peraturan perundangundangan dan apabila pengangkatan Camat itu tidak sesuai dengan ketentuan yang berlaku dapat dibatalkan keputusan pengangkatannya itu oleh Gubernur sebagai wakil Pemerintah Pusat.

Berpijak pada ketentuan pasal tersebut, maka ada 2 (dua) hal yang sangat penting yang perlu digarisbawahi dalam pengangkatan Camat sebagai PPAT Sementara, berupa : 1) camat dari pegawai negeri sipil; dan 2) menguasai pengetahuan teknis pemerintahan. Konsep pegawai negeri sipil menurut ketentuan Pasal 1 angka 3 UU Nomor 5 Tahun 2014 tentang Aparatur Sipil Negara adalah warga negara Indonesia yang memenuhi syarat tertentu, diangkat sebagai Pegawai Aparatur Sipil Negara secara tetap oleh pejabat pembina kepegawaian untuk menduduki jabatan pemerintahan. Kemudian dalam ketentuan Pasal 1 angka 7 UU Nomor 9 Tahun 2010 tentang Keprotokolan disebutkan bahwa pejabat pemerintah itu adalah pejabat yang menduduki jabatan tertentu dalam pemerintahan, baik di pusat maupun di daerah.

Senada dengan hal sebelumnya, Tedi Sudrajat juga telah mengkualifikasikan beberapa jenis pemangkuan jabatan yang diadakan guna kepentingan negara di Indonesia, yakni ${ }^{41}$ :

a. Jabatan Negara, yakni suatu lingkungan kerja tetap yang di dalamnya terkandung wewenang untuk menjalankan fungsi negara secara langsung atau bertindak untuk dan atas nama negara yang dilakukan oleh alat kelengkapan negara secara konstitusional. Biasanya istilah jabatan negara ini sering dipadupadankan dengan pejabat negara.

b. Jabatan Pemerintahan, yakni suatu lingkungan kerja tetap yang di dalamnya terkandung wewenang untuk menjalankan fungsi administrasi negara dan tidak bertindak untuk dan atas nama negara.

c. Jabatan Karier, yakni suatu jabatan struktural dan fungsional yang hanya dapat

Tedi Sudrajat, Hukum Birokrasi Pemerintahan; Kewenangan dan Jabatan, Jakarta: Sinar Grafika, 2017, hal. 79-91. 
diduduki oleh Pegawai Negeri Spil (PNS) setelah memenuhi syarat yang ditentukan.

d. Jabatan Publik merupakan suatu lingkungan kerja tetap yang didalamnya terkandung wewenang yang tugas pokoknya berkaitan dengan penyelenggaraan negara sesuai dengan ketentuan perundang-undangan yang berlaku.

Akhirnya dapat disimpulkan bahwa Camat itu merupakan bagian dari pejabat pemerintahan yang menduduki jabatan dalam institusi pemerintah daerah. Sehubungan dengan hal itu, maka adanya kebijakan hukum untuk menunjuk Camat sebagai PPAT Sementara telah menimbulkan diskrepansi jabatan dalam penyelenggaraan PPAT sebagai jabatan umum. Diskrepansi itu ditunjukkan dari adanya ketentuan Pasal 7 ayat 2 huruf b Peraturan Pemerintah Nomor 24 Tahun 2016 yang menentukan bahwa "melarang PPAT untuk merangkap jabatan dengan pegawai negeri..." Dengan adanya ketentuan tersebut, maka semakin mengukuhkan ketidakpastian hukum dalam penyelenggaraan jabatan PPAT Sementara. Namun dilain pihak, pada praktiknya penyelenggaraan jabatan PPAT Sementara juga masih dilaksanakan oleh Camat. Hal itu terjadi oleh karena dalam ketentuan Peraturan Pemerintah Nomor 24 Tahun 2016 masih membuka "kran" untuk terus dilaksanakannya pemangkuan jabatan PPAT Sementara oleh Camat. Hal ini terjadi oleh karena jabatan PPAT yang dipangku oleh Camat itu sudah berlaku cukup lama.

Meskipun jabatan PPAT yang dipangku oleh Camat sudah belangsung lama, namun kondisi pada masa lalu itu tidaklah secara mutlak berlaku untuk era sekarang ini, belum tentu konsep PPAT pada masa lalu itu relevan dengan masa sekarang. Dalam hal ini, pada awal kemerdekaan tentunya pejabat PPAT belumlah banyak, sehingga ditunjuklah pejabat-pejabat pada tubuh pemerintahan untuk mengemban jabatan PPAT. Secara historis, jika kita mundur lagi ke belakang, awalnya jabatan PPAT itu tidaklah dikenal dalam sistem peralihan tanah pada era Hindia-
Belanda, namun tunduk pada Peraturan Jabatan Notaris (Stb. 1860:3). B.F. Sihombing ${ }^{42}$ dalam bukunya Sistem Hukum PPAT dalam Hukum Tanah Indonesia mengemukakan bahwa pada era Hindia Belanda, kegiatan pemindahan Hak Atas Tanah diselenggarakan oleh Notaris dikarenakan akta pemindahan hak pada waktu itu didasarkan pada KUH-Perdata. Kemudian setelah Indonesia merdeka, eksistensi Notaris itu masih juga eksis dalam proses peralihan Hak Atas Tanah oleh karena Pemerintah Indonesia pada waktu itu sangat membutuhkan data-data akta pemindahan hak yang telah dibuat dan didaftarkan pada Kementerian Kehakiman. Dalam hal itu, adanya kewenangan Kementerian Kehakiman dalam peralihan hak atas tanah dikarenakan pada Kementerian Kehakiman itu melekat kewenangan untuk menentukan status warga negara. Sementara pada saat itu banyak kepemilikan tanah, umumnya dikuasai dan dikerjakan oleh Pemerintah HindiaBelanda, Badan Hukum Belanda, warga negara Belanda dan Timur Asing. Oleh karena itu, kehadiran Notaris sangatlah dibutuhkan oleh Pemerintah adalah untuk mendapatkan datadata kepemilikan tanah yang dimiliki oleh Pemerintah Belanda dan warga negara asing tersebut dan pada saat ini, Kementerian Agraria belumlah terbentuk.

Kemudian sekitar tahun 1948, didirikanlah sebuah Panitia Agraria dengan Penetapan Presiden tertanggal 21 Mei 1948 Nomor 16.43 Di tahun-tahun selanjutnya, Panitia Agraria ini dirasakan tidak sesuai lagi dengan keadaan, maka dengan Keputusan Presiden tanggal 19 Maret 1951 Nomor 36 membubarkan Panitia Agraria tersebut. ${ }^{44}$ Lantas, pada tahun 1953 dengan Keputusan Presiden tanggal 30 Juli 1953 Nomor 132, diadakanlah jabatan Menteri Agraria, sementara Kementerian Agraria baru dibentuk pada tahun 1955 dengan Keputusan

\footnotetext{
42 Lihat dalam B.F. Sihombing, Sistem Hukum PPAT dalam Hukum Tanah Indonesia, Jakarta: Kencana, 2019, hal. $1-35$.

43 Sudikno Mertokusumo, Perundang-Undangan Agraria Indonesia, Yogyakarta: 2011, hal. 105.

44 Ibid.
} 
Presiden tanggal 29 Maret 1955 Nomor $55 .{ }^{45}$ Kendati Kementerian Agraria telah dibentuk berdasarkan Keputusan Presiden Nomor 55 Tahun 1955, namun kewenangan pengalihan pemindahan izin pemindahan hak masih berada di Kementerian Kehakiman. ${ }^{46}$

Selanjutnya pada tahun 1956, dengan keputusan Presiden tanggal 14 Januari 1956 Nomor 1/1956 dibentuklah Panitia Negara Urusan Agraria yang berkedudukan di Jakarta. Panitia ini bertugas untuk menyusun dan mengajukan rencana undang-undang pokok agraria dengan amanat Presiden tanggal 24 April 1958 Nomor Bof/Hk/58 kepada Dewan Perwakilan Rakyat. $^{47}$ Langkah ini diambil Pemerintah dalam rangka untuk mengambil tanah-tanah milik barat sebagai wujud reformasi agraria. Langkah itu pula yang melahirkan kontruksi hukum baru yang pada esensinya tidak mengenal lagi dualisme hak atas tanah, di mana dulunya dikenal hak barat yang pengurusan peralihan Hak Atas Tanah dilakukan di Notaris, sementara hak adat itu peralihannya diselenggarakan oleh Kepala Desa atau Kepala Suku. ${ }^{48}$

Sihombing ${ }^{49}$ menguraikan bahwa setelah reformasi agraria, semua hak atas tanah diperlakukan sama dan harus didaftarkan, sehingga dengan berlakunya Undang Undang Pokok Agraria dan beserta berbagai ketentuan pelaksananya, peralihan hak atas tanah dipandang perlu ditingkatkan lebih tinggi dan diatur sendiri. Peralihan hak adat tidak lagi dibuat dihadapan Kepala Desa/ Kepala Suku dan secara dibawah tangan, namun harus dibuat dihadapan PPAT yang diangkat oleh Menteri Dalam Negeri cq. Direktorat Jenderal Agraria. Ketentuan yang memerintahkan bahwa kewajiban untuk membuat akta peralihan hak atas tanah dihadapan PPAT itu terdapat di dalam Pasal 19 Peraturan Pemerintah Nomor 10 Tahun 1961. Namun konsep PPAT dalam Peraturan Pemerintah Nomor 10 Tahun 1961

\footnotetext{
45 Ibid.

46 B.F. Sihombing, Sistem Hukum PPAT... hal. 1-35.

47 Sudikno Mertokusumo, Perundang-Undangan... hal. 105.

48 B.F. Sihombing, Sistem Hukum PPAT... hal. 1-35.

49 Ibid.
}

itu mengambil konsep penjabat yang ditunjuk oleh Menteri Agraria meskipun di dalam Peraturan Menteri Agraria Nomor 10 Tahun 1961 mengambil konsep pejabat yang bertugas membuat akte perjanjian yang dimaksudkan dalam Pasal 19 Peraturan Pemerintah Nomor 10 tahun 1961. Terhadap hal itu, Samsaimun memahaminya dalam arti bahwa pejabat itu sebagai penjabat pembuat akta tanah. ${ }^{50}$ Dalam hal itu, Pasal 3 ayat (1) Peraturan Menteri Agraria Nomor 10 Tahun 1961 menyebutkan bahwa yang dapat diangkat sebagai pejabat adalah:

a. Notaris;

b. Pegawai-pegawai dan bekas pegawai dalam lingkungan Departemen Agraria yang dianggap mempunyai pengetahuan yang cukup tentang peraturan-peraturan Pendaftaran Tanah dan peraturanperaturan lainnya yang bersangkutan dengan persoalan peralihan hak atas tanah;

c. Para pegawai pamongpraja yang pernah melakukan tugas seorang pejabat;

d. Orang-orang lain yang telah lulus dalam ujian yang diadakan oleh Menteri Agraria.

Berdasarkan uraian landasan sejarah di atas, dapat dipahami 2 (dua) hal penting, yakni: 1) Dasar beralihnya kewenangan Notaris kepada PPAT dalam mengurusi peralihan Hak Atas Tanah; dan 2) Dasar munculnya kewenangan Camat untuk melaksanakan tugas PPAT. Terhadap hal yang pertama disebutkan, dapat dilihat bahwa pada awalnya, peralihan Hak Atas Tanah merupakan tugas dari Notaris, namun kewenangan itu dialihkan kepada PPAT sebagai wujud politik reformasi agraria yang tidak mengenal lagi dualisme kepemilikan Hak Atas Tanah, di mana dulunya Notaris hanya menginventarisasi peralihan kepemilikan hak barat saja. Namun, sebagai akibat tidak dikenal lagi penggolongan penduduk sebagaimana dikenal pada era Hindia-Belanda layaknya diatur dalam Indische Staatsregeling (IS), tentunya notaris wajib menyelenggarakan pelayanan hukum atas pembuatan akta otentik kepada

50 Samsaimun, Peraturan Jabatan PPAT, Bandung: Pustaka Reka Cipta, 2018, hal. 187. 
seluruh masyarakat tanpa adanya diskriminasi ras, etnis, suku dan agama. Dengan sebab itu, seharusnya menyangkut peralihan Hak Atas Tanah itu dikembalikan lagi kepada Notaris. Alasannya, bidang peralihan Hak Atas Tanah itu juga merupakan bagian dari pekerjaan Notaris. Sebagaimana sudah dimaklumi bahwa notaris di Indonesia tunduk pada tradisi latijnse notariat, ${ }^{51}$ di mana latijnse notariat itu berwenang dalam ranah hukum perdata untuk mengontrol legal validity of transaction dan authenticate contract pada tiga area pelayanan saja, yakni real property services; family services; dan corporate services. ${ }^{52} \mathrm{Di}$ samping itu, sekarang ini juga tidak dikenal lagi hak barat dan hak adat yang dapat membatasi gerak Notaris dalam membuat akta otentik. Jika hal ini diakomodasi, tentunya masalah legitimasi akta PPAT sebagai akta otentik akan dapat diatasi dan menyangkut segala persoalan legal validity of transaction dan authenticate contract dalam ranah hukum perdata akan berada pada satu pintu yang dikelola oleh lembaga Notaris.

Namun apabila uraian sebelumnya itu ditolak, maka sebagai akibat sudah lama lembaga PPAT mengurusi peralihan Hak Atas Tanah sebagai lembaga otonom sebagaimana telah dikemukakan terdahulu, maka adanya Camat sebagai PPAT untuk melaksanakan dan membuat akta PPAT itu dapat dipahami. Alasannya, pada awal kemerdekaan tentunya belum banyak orang menjadi PPAT, meskipun Peraturan Menteri Agraria Nomor 10 Tahun 1961 juga menyebutkan bahwa yang dapat diangkat sebagai pejabat PPAT itu termasuk Notaris. Namun pada awal kemerdekaan, jabatan Notaris itu masih dijabat oleh para pejabat yang berasal dari zaman Pemerintahan Belanda dan banyak Notaris yang berkewarganegaraan Belanda pulang kembali ke negara asalnya, sementara notarisnotaris yang ada di Indonesia pada waktu itu

Ditinjau dari sudut tradisi hukum, dikenal ada dua model pemangkuan jabatan notaris di dunia, yakni latin notary tradition dan notary public tradition.

52 Roger Van den Bergh \& Yves Montangie, Competition In Profesional Services Market; Are Latin Notaries Different?, Journal of Competition Law and Economics, Vol. 2 No. 2, 2006, hal. 189. sangat sedikit, ${ }^{53}$ sehingga pemangku jabatan Notaris pun terjadi kekosongan pejabat yang memangku jabatan Notaris. Melalui alasan itu, diambillah kebijakan untuk menunjuk pejabat PPAT kepada pegawai-pegawai atau bekas pegawai di lingkungan Departemen Agraria dan pegawai-pegawai pamong praja. Dalam hal ini, tentunya Camat juga termasuk ke dalam pegawai-pegawai yang dimaksudkan itu.

Selanjutnya seiring dengan perkembangan hukum menyangkut ke-PPAT-an, konsep Camat sebagai PPAT, sekarang ini telah digeser politik hukumnya menjadi "di daerah yang belum cukup terdapat PPAT”, di mana kontruksi pada awalnya menegaskan bahwa "untuk setiap Kecamatan atau daerah yang disamakan dengan itu, diangkat seorang penjabat pembuat akta tanah”. Pergeseran itu dapat dibenarkan karena pada awalnya menganut prinsip setiap kecamatan itu ada satu PPAT (Camat) oleh karena terjadi kekurangan PPAT, kemudian beralih ke daerahdaerah atau tempat-tempat yang belum terdapat PPAT oleh karena terjadi kekosongan PPAT. Dengan kata lain, tidak ada lagi sentralisasi PPAT pada setiap kecamatan, namun hanya pada daerah pedalaman atau kecamatan terjauh saja yang ditempatkan PPAT Sementara. Namun harus disadari pula bahwa pengangkatan Camat sebagai PPAT Sementara tidaklah relevan lagi sebagai akibat dapat menimbulkan pertentangan norma. Sekarang ini, sudah jelas dikontruksikan bahwa PPAT itu merupakan pemangku jabatan umum sehingga PPAT dapat disebut sebagai pejabat umum dan tidak boleh merangkap jabatan sebagai pajabat pemerintah. Dengan demikian, Camat sebagai pejabat pemerintah yang ditunjuk karena jabatannya untuk melaksanakan tugas PPAT adalah sebuah ketidakpastian hukum. Oleh sebab itu, sebagai akibat adanya norma yang melarang PPAT untuk merangkap jabatan dengan pegawai negeri di dalam tubuh Peraturan Pemerintah Nomor 24 Tahun 2016 telah memunculkan kritik untuk dilakukan evaluasi norma terhadap peraturan jabatan PPAT.

\footnotetext{
53 Komar Andasasmita, Notaris I, Jawa Barat: Ikatan Notaris Indonesia, 1991, hal. 951.
} 


\section{Penyelenggaraan PPAT Sementara di Masa Depan}

Didasarkan pada paparan subbab sebelumnya, sudah dapat dikatakan bahwa diperlukan adanya suatu evaluasi hukum akan keberadaan norma hukum yang eksis berlaku saat ini dalam hubungannya dengan PPAT. Oleh sebab itu, diperlukan perubahan hukum dalam penyelenggaraan PPAT Sementara demi terciptanya sistem ke-PPAT-an yang baik, sehingga penting rasanya ditawarkan suatu konsep baru yang membicarakan tentang PPAT Sementara. Dasar pemikiran yang melandasi untuk diadakannya perubahan hukum itu disebabkan karena dalam berhukum itu hanya ada 2 (dua) aspek, yaitu pembentukan hukum dan pelaksanaan atau penegakan hukum. ${ }^{54}$ Dalam konteks pembuatan hukum, Satjipto Rahardjo menegaskan bahwa bahan pembuatan hukum dimulai sebagai gagasan atau ide yang kemudian diproses lebih lanjut sehingga pada akhirnya benar-benar menjadi bahan yang siap untuk diberi sanksi hukum. Gagasan ini muncul dalam bentuk keinginan agar suatu masalah diatur oleh hukum demi tercapainya perlindungan hukum bagi masyarakat. ${ }^{55}$

Keluwesan untuk memberikan gagasan atau ide itu sejalan dengan konsep negara hukum yang dianut Indonesia, di mana dituntut untuk selalu membentuk hukum yang responsif dan protektif untuk mencapai tujuan negara. Oleh karena itu, analisis dan evaluasi hukum bukan hanya dilakukan oleh pihak legislatif dan eksekutif saja, melainkan juga dapat dilakukan oleh masyarakat agar dapat tercapainya keadilan hukum. Hal ini didasari pada pemahaman bahwa keadilan itu sangat penting untuk dijamin dalam perundangundangan di setiap negara agar tidak munculnya kekuasaan yang absolut dalam pengelolaan negara, sehingga undang-undang itu bukan hanya sebagai alat pengatur dan pemaksa, tetapi

\footnotetext{
$54 \quad$ Arief Hidayat, "Konsep dan Implementasi Negara Hukum Pancasila dalam Mengatasi Permasalahan Hukum Nasional" Makalah dalam Seminar Nasional "Konsep dan Implementasi Negara Hukum Pancasila Dalam Mengatasi Permasahanan Hukum Nasional" di Semarang pada tanggal 30 September 2017. hal. 7.

55 Satjipto Rahardjo, Ilmu Hukum, Bandung: PT Citra Aditya Bakti, 2014, hal 187.
}

juga sebagai alat pembatas kekuasaan negara itu sendiri. ${ }^{56}$ Dengan adanya fungsi undang-undang sebagaimana tersebut sebelumnya itu, maka sangatlah dibutuhkan suatu telaah norma hukum dan sebuah tawaran solusi demi menyesuaikan dengan perkembangan kebutuhan hukum di dalam masyarakat.

Berpijak pada paparan sebelumnya, maka dalam rangka melakukan evaluasi terhadap ketentuan PPAT Sementara dapat dilaksanakan dengan menunjuk kepala desa sebagai penerima beban tugas PPAT Sementara di daerah-daerah yang tidak cukup PPAT. Hal ini dilakukan sebagai upaya mengganti konsep hukum sebelumnya yang mendayagunakan peran Camat sebagai PPAT Sementara yang dinilai telah menimbulkan kerancuan yuridik atau ketidakpastian hukum dalam pengembanan tugas jabatan PPAT. Penunjukan kepala desa sebagai PPAT Sementara itu juga sejalan dengan kondisi pemerintahan daerah yang ada selama ini, di mana asas otonomi dan tugas pembantuan sangat ditekankan dalam mengembangkan daerah-daerah. Oleh karena itu, dapat dikatakan bahwa peran kepala desa dalam membangun daerah adalah juga sangat berpengaruh bagi kemashalatan masyarakat.

Uraian di atas itu didasari pada argumentasi bahwa konsep otonomi daerah telah membawa "paradigma baru" bagi daerah untuk bisa membangun dan mengembangkan daerahnya sesuai dengan kebutuhan masyarakatnya. RB Soemanto menjelaskan bahwa otonomi daerah memiliki kewenangan mengatur dan mengurus kepentingan masyarakat. Prakarsa daerah yang dilakukan berdasarkan aspirasi dan kebutuhan masyarakat adalah satu rumusan ideal; sekalipun begitu isi dan bentuk yang dibutuhkan untuk pelaksanaannya cukup rumit. ${ }^{57}$

56 Yos Johan Utama, 2010, Membangun Peradilan Tata Usaha Negara yang Berwibawa, Naskah Pidato Pengukuhan Jabatan Guru Besar dalam Bidang Ilmu Hukum pada Fakulas Hukum Universitas Diponegoro, Semarang: Universitas Diponegoro, 2010, hal. 2-3.

57 RBSoemanto, "Tantangan Pelaksanaan Otonomi Daerah: Perspektif Hukum dan Perubahan Sosial", Naskah Pidato Pengukuhan Jabatan Guru Besar Sosiologi Hukum Pada Fukultas Ilmu Sosial dan Ilmu Politik Universitas Sebelas Maret, Surakarta, Universitas Sebelas Maret, 2007, hal. 2. 
Disamping itu, alasan pemilihan kepala desa lebih tepat didayagunakan sebagai PPAT Sementara adalah sebagai akibat status kepala desa itu yang dapat dikategorikan sebagai masyarakat sipil (bukan Aparatur Sipil Negara) yang didapuk menjadi kepala desa. Dalam hal ini, Asep Suparman menjelaskan bahwa apabila kedudukan kepala desa itu dipandang dalam perspektif status kepegawaian negara, maka jelas kepala desa itu bukanlah merupakan Pejabat Tata Usaha Negara, meskipun kepala desa itu menjalankan urusan pemerintahan umum, pemerintahan daerah dan desa. ${ }^{58}$ Dengan demikian, apabila kepala desa yang didayagunakan untuk menjadi PPAT Sementara, tentunya akan lebih memberikan koherensi norma dan tentunya mengangkat nilai kepastian hukum pada tempatnya.

Kemudian argumentasi lainnya yang dipandang mendukung agar PPAT-Sementara itu seharusnya diemban oleh seorang kepala desa adalah diperkuat oleh Yurisprudensi Mahkamah Agung dalam perkara Nomor 665 K/Sip/1979 Tanggal $22-7$ - 1980. Dalam Yurisprudensi tersebut itu ditegaskan bahwa "dengan telah tercapainya jual beli antara penjual dan pembeli yang diketahui oleh Kepala Kampung yang bersangkutan dan dihadiri oleh 2 (dua) orang saksi serta diterimanya harga pembelian oleh penjual, maka jual beli itu sudah sah menurut hukum, sekalipun belum dilaksanakan dihadapan PPAT". Hal demikian itu telah memberikan justifikasi akan keberadaan kepala desa $^{59}$ sebagai pemimpin yang lebih tahu akan fakta historis dan sosiologis kondisi daerahnya dalam memberikan pelayanan hukum di

58 Asep Suparman, "Kedudukan Kepala Desa Menurut Undang-Undang Nomor 5 Tahun 1986, Jurnal Wawasan Hukum, Vol. 28, No. 1, 2013, hal. 647-648.

59 Disini disebut sebagai Kepala Desa karena sekarang ini UU Nomor 6 Tahun 2014 tentang Desa menamai unsur penyelenggara Pemerintah Desa itu sebagai Kepala Desa. Namun UU tersebut tidak secara mutlak membatasi penamaan pimpinan suatu wilayah masyarakat hukum, melainkan penamaan lainnya sesuai dengan kearifan lokalnya tetap diakui dengan frasa "Kepala Desa atau yang disebut dengan nama lain" Oleh sebab itu, penulis memandang penamaan Kepala Desa atau Kepala Kampung itu sebagai satu kesatuan arti meskipun dengan istilan yang berbeda. daerah yang tidak terdapat PPAT. Terlebih lagi, pengadilan sebagai tempat masyarakat mengadu jika terjadi sengketa/konflik mengenai kepemilikan tanah, pemutus perkara (hakim) pengadilan juga mengakui keberadaan kepala desa dalam transaksi dengan objek tanah dan mengakui transaksi itu sah menurut hukum.

Meskipun demikian, jika gagasan di atas itu disepakati, bukan berarti kepala desa itu dapat serta-merta langsung bisa diangkat menjadi PPAT Sementara. Namun dalam pengangkatan kepala desa sebagai PPAT Sementara itu tentunya dengan tetap mengetengahkan syarat-syarat dan tata cara pengangkatan PPAT Sementara. Diantaranya adalah syarat untuk diangkat menjadi PPAT Sementara itu adalah dengan mengikuti pendidikan dan pelatihan yang diselenggarakan oleh Badan Pertanahan Nasional (BPN) yang penyelenggaraannya dapat bekerja sama dengan organisasi profesi PPAT. Tujuan diadakannya pendidikan dan pelatihan tersebut adalah dalam rangka untuk menambah kemampuan PPAT Sementara dalam melaksanakan tugas jabatannya sebagai pejabat umum. Pendidikan dan pelatihan itu dilaksanakan oleh karena banyaknya peraturan bidang keagrariaan yang belum dapat dipahami dan dikuasai dengan baik oleh kepala desa, sehingga berpotensi terjadinya kesalahan dalam pembuatan akta dibidang ke-PPAT-an. Oleh karena itu, dibutuhkan pendidikan dan pelatihan tambahan bagi kepala desa dalam memahami perkembangan hukum, khususnya bidang Hak Atas Tanah yang terus berkembang mengikuti kebutuhan hukum masyarakat.

\section{Penutup}

\section{A. Kesimpulan}

Kesimpulan yang dapat diambil dari artikel ini adalah adanya diskrepansi norma dalam penyelenggaraan jabatan PPAT Sementara. Ketidakcocokan itu berkonsekuensi terhadap adanya ketidakpastian hukum akan keberadaan norma hukum terkait penyematan gelar jabatan PPAT Sementara kepada Camat, di mana Camat itu merupakan Pejabat Tata Usaha Negara (Aparatur Sipil Negara) dan 
mempunyai tugas untuk menyelenggarakan tugas-tugas Pemerintahan di kecamatankecamatan sebagai perpanjangan tangan dari pemerintah daerah kabupaten/kota, yang tentunya bertentangan dengan aturan Jabatan PPAT. Sebagai akibat adanya hal demikian itu, sudah seharusnya pengembanan tugas PPAT Sementara dialihkan kepada kepala desa, di mana keberadaan kepala desa itu juga diakomodasi dalam ketentuan jabatan PPAT sebagai PPAT Sementara. Hal itu dianggap lebih memberikan kepastian hukum dan merupakan solusi ideal untuk merubah status Camat dalam pemangkuan PPAT Sementara.

\section{B. Saran}

Melalui artikel ini, penulis memberikan saran dan berharap kepada para pemangku kepentingan dibidang pertanahan, khususnya di bidang PPAT agar dapat melakukan pengkajian yang mendalam lagi terhadap gagasan dalam artikel ini untuk dapat diimplementasikan sebagai langkah nyata dalam mewujudkan kepastian hukum dalam rangka mewujudkan tertib pendaftaran tanah di Indonesia.

\section{Daftar Pustaka}

\section{Jurnal, Makalah, dan Karya Ilmiah}

Bergh, Roger Van den \& Yves Montangie, "Competition In Profesional Services Market: Are Latin Notaries Different?", Journal of Competition Law and Economics, Vol. 2 No. 2, 2006.

Dewi, Iga Gangga Santi, "Peran Camat Selaku Pejabat Pembuat Akta Tanah (PPAT) dalam Jual Beli Tanah", Jurnal Pandecta, Vol. 5 No. 2, 2010.

Djumardin dan RR. Cahyowati, "Kewenangan Camat Dan Kepala Desa Sebagai Pejabat Pembuat Akta Tanah (PPAT) Setelah Berlakunya UUJN", Jurnal Notariil, Vol. 2, No. 2, 2017.
Ervina, Vuji, "Pelayanan Pendaftaran Tanah oleh Camat sebagai Pejabat Pembuat Akta Tanah (PPAT) Sementara di Kantor Kecamatan Dusun Selatan Kabupaten Barito Selatan, Jurnal Ilmu Politik dan Pemerintahan Lokal, Vol. 2, No. 2, 2013.

Ginting, Budiman, "Kepastian Hukum dan Implikasinya Terhadap Pertumbuhan Investasi di Indonesia", Naskah Pidato Pengukuhan Jabatan Guru Besar Tetap dalam Bidang Hukum Investasi Pada Fukultas Hukum Universitas Sumatera Utara, Medan, Universitas Sumatera Utara, 2008.

Harsono, Boedi, "Tugas dan Kedudukan Pejabat Pembuat Akta Tanah", Jurnal Hukum dan Pembangunan, Vol. 25 No. 6, 1995.

\section{"PPAT Sejarah, Tugas} Kewenangannya", Majalah Renvoi Nomor 844.IV Jakarta, 2007.

Hartono, Sri Redjeki, "Perspektif Hukum Bisnis Pada Era Teknologi”, Pidato Pengukuhan Jabatan Guru Besar Hukum Dagang pada Fakulas Hukum Universitas Diponegoro, Kampus UNDIP-Semarang, 18 Desember 1995.

Hidayat, Arief, "Konsep dan Implementasi Negara Hukum Pancasila dalam Mengatasi Permasalahan Hukum Nasional", Makalah dalam Seminar Nasional "Konsep dan Implementasi Negara Hukum Pancasila Dalam Mengatasi Permasahanan Hukum Nasional" di Semarang pada tanggal 30 September 2017.

Hartono, C.G.F Sunaryati, "Membangun Budaya Hukum Pancasila sebagai Bagian dari Sistem Hukum Nasional Indonesia di Abad 21", Jurnal Veritas Et Justitia, Vol. 1, No. 2, 2015.

Hamzah, "Kedudukan Camat Selaku Pejabat Pembuat Akta Tanah Sementara", Jurnal Transformasi Administrasi, Vol. 9 No. 2, 2019. 
Munthohar, Muhammad dan Amin Purnawan, "Tugas dan Kewenangan Camat sebagai PPAT Sementara dalam Pembuatan AktaAkta tentang Tanah: Studi di Kabupaten Boyolali”, Jurnal Akta, Vol. 4, No. 4, 2017.

Oloan, Nur, "Praktek Pembuatan Akta

Tanah oleh Camat dalam Kedudukan dan Fungsinya Selaku PPAT Sementara di Kota Padang Sidimpuan", Jurnal Pendidikan Ilmu-Ilmu Sosial, Vol. 8, No. 2, 2016.

Rahardjo, Satjipto, "Meningkatkan Kepastian Hukum dalam Rangka Pelaksanaan Keadilan Berdasarkan Pancasila", Jurnal Hukum dan Pembangunan Universitas Indonesia, Vol. 18 No. 6, 1988.

, "Peranan Notaris Sebagai

Pembuat Akta dalam Masa Pembangunan", Makalah, Simposium Fungsi Notaris dalam Pembangunan, Program Pendidikan Kenotariatan, Fakultas Hukum-Universitas Diponegoro, Semarang pada tanggal 29 Mei 1984.

Soemanto, RB, "Tantangan Pelaksanaan Otonomi Daerah: Perspektif Hukum dan Perubahan Sosial", Naskah Pidato Pengukuhan Jabatan Guru Besar Sosiologi Hukum pada Fakultas Ilmu Sosial dan Ilmu Politik Universitas Sebelas Maret, Surakarta, Universitas Sebelas Maret, 2007.

Sidharta, "Putusan Hakim; Antara Keadilan, Kepastian Hukum dan Kemanfaatan", dalam Bunga Rampai Komisi Yudisial, Reformasi Peradilan dan Tanggung Jawab Negara, Jakarta: Komisi Yudisial Republik Indonesia, 2010.

Saputra, Gusti Surya Hadi, "Batasan Waktu Sementara Terhadap Camat Sebagai PPAT Sementara", Calyptra; Jurnal Mahasiswa Universitas Surabaya, Vol. 3 No. 1, 2014.

Suparman, Asep, "Kedudukan Kepala Desa Menurut Undang-Undang Nomor 5 Tahun 1986", Jurnal Wawasan Hukum, Vol. 28, No. 1, 2013.
Utomo, Hatta Isnaini Wahyu dan Hendry Dwicahyo Wanda, "Prinsip Kehati-hatian Pejabat Pembuat Akta Tanah dalam Peralihan Tanah yang Belum Bersertifikat", Jurnal Hukum Ius Quia Iustum, Vol. 24, No. 3, 2017.

Utama, Yos Johan, "Membangun Peradilan Tata Usaha Negara yang Berwibawa”, Naskah Pidato Pengukuhan Jabatan Guru Besar dalam Bidang Ilmu Hukum pada Fakulas Hukum Universitas Diponegoro, Semarang: Universitas Diponegoro, 2010.

Wanda, Hendry Dwicahyo, "Prinsip Kehatihatian Pejabat Pembuat Akta Tanah dalam Pengurusan Peralihan Tanah "Letter C"”, Jurnal Masalah-Masalah Hukum, Vol. 46 No. 2, 2017.

Yunarko, Bambang, "Kedudukan Jabatan dan Akta Pejabat Pembuat Akta Tanah dalam Sengketa di Peradilan Tata Usaha Negara", Jurnal Perspektif, Vol. XVIII, No. 3, 2013.

Yoan, Ricki, Amzulian Rifai dan Amin Mansyur, "Tanggung Jawab Camat Selaku Pejabat Pembuat Akta Tanah Sementara Setelah Tidak Menjabat Lagi Terhadap Akta yang Dibuatnya”, Repertorium: Jurnal Ilmiah Hukum Kenotariatan, Vol. 6 No. 2, 2017.

\section{Buku}

Atmasasmita, Romli, Teori Hukum Integratif; Rekonstruksi Terhadap Teori Hukum Pembangunan dan Teori Hukum Progresif, Yogyakarta: Genta Publishing, 2012.

Assiddiqie, Jimly, Konstitusi Ekonomi, Jakarta: Kompas, 2010.

Adji, Habib, Beda Karakter Yuridis Antara Notaris dan PPAT Serta Akta Notaris-PPAT, dalam Satya Arinanto dan Ninuk Triyanti (Ed), Memahami Hukum; Dari Kontruksi Sampai Implementasi, Jakarta; Rajawali Press, 2012. , Meneropong Khazanah Notaris dan PPAT Indonesia, Jakarta: PT Citra Aditya Bakti, 2009. 
Andasasmita, Komar, Notaris I, Jawa Barat: Ikatan Notaris Indonesia, 1991.

Dirdjosisworo, Soedjono, Pengantar Ilmu Hukum, Jakarta: Rajawali Pers, 2016.

Diantha, I Made Pasek, Metodologi Penelitian Hukum Normatif dalam Justifikasi Teori Hukum, Jakarta: Kencana, 2019.

Hadjon, Philipus M. (et.all), Hukum Administrasi dan Tindak Pidana Korupsi, Yogyakarta: Gadjah Mada University Press, 2012.

Khairulnas dan Leny Agustan, Panduan Notaris/ PPAT dalam Menghadapi Gugatan Perdata, Yogyakarta: UII Press, 2018.

Mahfud MD, Moh, Membangun Politik Hukum, Menegakkan Konstitusi, Jakarta: Rajawali Pers, 2012.

Mas, Marwan, Pengantar Ilmu Hukum, Bogor: Ghalia Indonesia, 2014.

Mulyadi, Lilik, Seraut Wajah Putusan Hakim dalam Hukum Acara Perdata Indonesia, Bandung: PT Citra Aditya Bakti, 2015.

Marzuki, Peter Mahmud, Pengantar Ilmu Hukum, Edisi Revisi, Cet ke-5, Jakarta: Kencana, 2013.

Mertokusumo, Sudikno, Perundang-Undangan Agraria Inodnesia, Yogyakarta: 2011.

Sudrajat, Tedi, Hukum Birokrasi Pemerintahan; Kewenangan dan Jabatan, Jakarta: Sinar Grafika, 2017.

Samekto, FX Adji, Hukum dalam Lintasan Sejarah, Bandar Lampung: Indept Publishing, 2013.
Santoso, Urip, Hukum Agraria; Kajian Komprehensif, Jakarta: Kencana, 2014. , Pejabat Pembuat Akta Tanah; Perspektif Regulasi, Wewenang dan Sifat Akta, Jakarta: Kencana, 2016.

Soedjendro, J. Kartini, Perjanjian Peralihan Hak atas Tanah yang Berpotensi Konflik, Cet ke5, Yogyakarta: Kanisius, 2005.

Samsaimun, Peraturan Jabatan PPAT, Bandung: Pustaka Reka Cipta, 2018.

Sumardjono, Maria S.W. dan Martin Samosir, Hukum Pertanahan dalam Berbagai Aspek, Medan: Bina Media, 2000.

Sukirno, Politik Hukum Pengakuan Hak Ulayat, Jakarta: Kencana, 2018.

Salim HS, Teknik Pembuatan Akta Pejabat Pembuat Akta Tanah, Jakarta: Rajawali Pers, 2016. , Peraturan Jabatan dan Kode Etik Pejabat Pembuat Akta Tanah (PPAT), Jakarta: Rajawali Pers, 2019.

SF Marbun, Hukum Administrasi Negara I, Yogyakarta: FH UII Press, 2018.

Sihombing, B.F, Sistem Hukum PPAT dalam Hukum Tanah Indonesia, Jakarta: Kencana, 2019.

Ridwan HR, Hukum Administrasi Negara Ed. Revisi, Jakarta: Rajawali Pers, 2017.

Rahardjo, Satjipto, Ilmu Hukum, Bandung: PT Citra Aditya Bakti, 2014. 